\title{
THE CHOICE OF PREPARATION METHOD FOR THE DETERMINATION OF Alternaria TOXINS FROM WHEAT SAMPLES BY LC-MS/MS
}

\author{
Elizabet P. Janić Hajnal*1, Dejan Z. Orčić ${ }^{2}$, Jasna S. Mastilović ${ }^{1}$, Ivan Lj. Milovanović ${ }^{1}$, Jovana J. Kos ${ }^{1}$ \\ ${ }^{1}$ University of Novi Sad, Institute for Food Technology, 21000 Novi Sad, \\ Bulevar cara Lazara 1, Serbia \\ ${ }^{2}$ University of Novi Sad, Faculty of Sciences, 21000 Novi Sad, \\ Trg Dositeja Obradovića 3, Serbia
}

*Corresponding author:
Phone: +381214853624
Fax: +38121450725
E-mail address: elizabet.janich@fins.uns.ac.rs

\begin{abstract}
Cereals are the primary source of human diet, wheat being the third most produced grain worldwide, and in Serbia second most produced grain, just behind corn. As a result of climate change and global warming, frequent occurrences of mycobiota on steep grains can produce a negative impact on the safety of food products and their quality, which inevitably leads to large economic losses. Although Fusarium spp. remains a main source of mycotoxins contamination of wheat, in recent years, due to the evident climatic changes affecting agricultural production, other mycotoxigenic fungi have been pointed out as important wheat contaminants. Among them are the fungi of the genus Alternaria, especially $A$. alternata, which under favourable conditions, produces mycotoxins such as alternariol, alternariol monomethyl ether, tenuazonic acid, and other Alternaria toxins. Taking into account the toxicity of metabolites produced by certain species of fungi of the genus Alternaria in the system from farm to table, it is necessary to develop specific and sensitive analytical methods in order to implement systematic controls of occurrence of Alternaria toxins. Liquid chromatography coupled to (tandem) mass spectrometry (LC-MS/MS) has become the technique of choice for the detection and quantification of Alternaria toxins in food and feed. There are several limiting factors such as the efficiency of sample cleanup and the lack of reference materials for food and feed. The aim of this study was to to choose the most suitable preparation method for the determination of Alternaria toxins from wheat samples by LC-MS/MS technique based on published sample preparation methods, with possible modifications, which are used in analysis of mycotoxins. Modified method of wheat samples preparation by extraction with ethyl acetate was selected as acceptable based on extraction efficiency of analytes of interest.
\end{abstract}

Key words: Alternaria toxins, preparation methods, wheat, LC-MS/MS

\section{INTRODUCTION}

Alternaria toxins are mycotoxins produced by Alternaria species that cause plant diseases on many crops. They are widespread in both humid and semi-arid regions and can infect growing plants in the field. Toxin production is affected by interactions among Alternaria strain, the growing substrate and the environmental conditions (Barkai-Golan, 2008). Alternaria species are the principal contaminating fungi in wheat, sorghum and barley (Deshpande, 2002). Beside cereals, they have been reported to occur in oilseeds (sunflower and rapeseed), tomato, apples, citrus fruits, olives and several other fruits and vegetables, wine and beer (Scott and Kanhere, 2001; Scott, 2006; Ostry, 2008; Fernandez-Cruz et al., 2010; Scott et al., 
2012). Alternaria species produce more than 70 secondary metabolites, but a small proportion of these phytotoxins have been chemically characterised and reported to act as mycotoxins in humans and animals (Bottailico and Logrieco, 1992; Barkai-Golan, 2008). Alternaria toxins are divided into 5 different classes based on their chemical structures: (1) dibenzo- $\alpha$-pyrones which include alternariol $(\mathrm{AOH})$, alternariol monomethyl ether (AME), altenuene (ALT); (2) tenuazonic acid (TeA) and iso-tenuazonic acid (isoTeA); (3), perylene quinones which include altertoxins I, II and III (ATX-I, ATX-II and ATX-III), and stemphyltoxin III; (4) AALtoxins (AAL-TA and AAL-TB), abbreviation for A. alternata f. sp. lycopersici toxins; (5) a cyclic tetrapeptide such as tentoxin (TEN) (EFSA, 2011). From a toxicological point of view, there is strong evidence that $\mathrm{AOH}$ and $\mathrm{AME}$ could be mutagenic (An et al., 1989; Brugger et al., 2006). Although the acute toxicity of $\mathrm{AOH}$ and AME in mice is low (LD ${ }_{50}: 400 \mathrm{mg} \mathrm{kg}^{-1}$ bw), both compounds show remarkable cytotoxicity in cell cultures (Pero et al, 1973). Furthermore, it has been suggested that $\mathrm{AOH}$ and AME produced by Alternaria alternata on grain might be a factor responsible for the increased incidence of human oesophageal cancer in China (Liu et al., 1992; Pero et al., 1973). The methods of analysis of Alternaria toxins have been reviewed by Scott (2001) and more recently by Ostry (2008), Shephard et al. (2009, 2010, 2011, 2012, 2013), Köppen et al. (2010) and Berthiller et al. (2014). Several chromatography based techniques are suitable for Alternaria toxin quantification in foods and feeds, and liquid chromatography coupled to (tandem) mass spectrometry has become the method of choice for their determination. However, there are several limiting factors for the analysis of Alternaria toxins such as the efficiency of sample cleanup, the availability of (sufficient) amounts of standards and the lack of reference materials for food and feed. Most of the analytical methods are to a certain extent in-house validated but interlaboratory validation studies, standardisation of the analytical methods or conduction of proficiency tests have not been reported (EFSA, 2011). Currently there are no regulations on Alternaria toxins in food and feed in Europe or in other regions of the world.

\section{MATERIAL AND METHODS}

\section{Samples}

Blank wheat sample free from the analytes of interest (TeA, AOH, AME) were collected from various growing regions in Vojvodina, Republic of Serbia.

\section{Chemicals and reagents}

Alternariol $(\mathrm{AOH})$ (purity 99.0\%), alternariol monomethyl ether (AME) (purity 99.5\%), and tenuazonic acid (TeA) (purity 99.5\%) were purchased from SigmaAldrich (Saint Louis, USA). Stock solutions of $\mathrm{AOH}, \mathrm{AME}$ and TeA were prepared in methanol and stored at $-20{ }^{\circ} \mathrm{C}$. The following solvents were used: methanol $(\mathrm{MeOH}) \quad$ (J.T.Baker, Deventer, The Netherlands) and ethyl acetate (EtOAc) (Sigma-Aldrich, Saint Louis, USA), all LCMS grade, methanol (MeOH) and acetonitrile (ACN) (J.T.Baker, Deventer, The Netherlands), and dimethylformamide (DMF) (Sigma-Aldrich, Saint Louis, USA), all HPLC grade, formic acid (FA) (purity 99.9\%, ) (Carlo Erba, Italy), acetic acid (AA) (purity 99.8\%), pa (lach - ner, Czech Repablic), fuming $\mathrm{HCl}$ (37\%), pa, (Merck, Darmstadt, Germany), magnesium sulfate - anhydrous $\left(\mathrm{MgSO}_{4}\right)$ (purity $\geq 99.5 \%$ ) (Sigma-Aldrich, Saint Louis, USA), sodium chloride ( $\mathrm{NaCl}$ ) (purity 99.9\%) (Panreac, Barcelona, Spain). Deionized water was sourced from a Millipore Simplicity UV water purification system (Bedford, MA, USA).

\section{Sample preparation}

In order to overcome irregular mycotoxins distribution, sampling was performed according to EU requirements (2006/401/EC). Average blank wheat sample of approximately $10 \mathrm{~kg}$ was homogenized and quartered to obtain a $500 \mathrm{~g}$ of laboratory sample. Sample was ground to a $1 \mathrm{~mm}$ particle size using laboratory mill (Knifetec $^{\top M} 1095$ mill, Foss, Hoganas, Sweden).

The first method of sample preparation (Streit et al, 2013) was performed as follows: $5 \mathrm{~g}$ of homogenized wheat flour samples were extracted by shaking with 
$20 \mathrm{~mL}$ of acetonitrile/water/acetic acid mixture $(79: 20: 1, v / v / v)$ for one hour, using an automatic shaker. Afterward, the suspensions were filtered and approx. $10 \mathrm{~mL}$ (exact volume known) of filtered crude extracts were transferred into glass cuvette, and evaporated under a stream of $\mathrm{N}_{2}$ (Reacti-Therm I \#18821, Thermo Scientific, USA). The dry residue was dissolved in $1 \mathrm{~mL}$ of DMF, and transferred to an HPLC vial through a $0.2 \mu \mathrm{m}$ PTFE syringe filter (Econofilter, Agilent Technology, Germany).

The second method of sample preparation (Streit et al, 2013) was performed as follows: $5 \mathrm{~g}$ of homogenized wheat flour samples were extracted by shaking with $20 \mathrm{~mL}$ of acetonitrile/water/acetic acid mixture (79:20:1,v/v/v) for one hour, using an automatic shaker. Afterward, the suspensions were filtered and aliquots $(1 \mathrm{~mL})$ of filtered crude extracts were transferred into glass vials and diluted with $1 \mathrm{ml}$ of mobile phase. Before injection into the liquid chromatography system, the extracts were passed through the $0.2 \mu \mathrm{m} \mathrm{RC}$ syringe filter.

The third method of sample preparation (Agilent application by authors: Reinhold and Bartels, 2010) was performed as follows: $20 \mathrm{~g}$ of the homogenized blank wheat flour samples were extracted by shaking with $60 \mathrm{~mL}$ of acetonitrile/methanol/ water mixture $(\mathrm{pH} \mathrm{3;} \mathrm{45:10:45} \mathrm{v/v/v)}$ for at least 2 min with an ultra-fast mixer. Then, they were centrifuged at $4000 \mathrm{rpm}$ for $10 \mathrm{~min}$ and $6 \mathrm{~mL}$ of the supernatant was transferred to a centrifuge tube and was diluted with $15 \mathrm{~mL}$ of $0.05 \mathrm{M}$ sodium dihydrogen phosphate solution $(\mathrm{pH} 3)$. The extract was cleaned up and concentrated by solid phase extraction using Bond Elut Plexa hydroxylated polymer cartridges (200 mg, 6 mL, Agilent Technology, US). After conditioning of cartridge with $5 \mathrm{~mL}$ methanol, followed by $5 \mathrm{~mL}$ of water, the diluted extract was passed through SPE tube. The centrifuge tube was rinsed with water and rinse loaded through the SPE tube. The SPE tube was then washed with $5 \mathrm{~mL}$ water, dried for $10 \mathrm{~min}$ under light vacuum and eluted with $5 \mathrm{~mL}$ methanol, followed by $5 \mathrm{~mL}$ of acetonitrile. Eluate was evaporated to dryness, reconstituted in $1 \mathrm{~mL}$ water/methanol $(70: 30, \mathrm{v} / \mathrm{v})$, and passed through the $0.45 \mu \mathrm{m} \mathrm{RC}$ syringe filter.

The fourth method of sample preparation (Rasmussen et al, 2010) was performed as follows: A modification of the QuEChERS procedure (Annastassiades et al, 2003), used mainly for pesticide residue analysis, was employed for isolation of analytes. Briefly, $4 \mathrm{~g}$ of homogenous representative samples were weighted into the PTFE cuvette and $7.5 \mathrm{~mL}$ of $0.1 \%(\mathrm{v} / \mathrm{v})$ formic acid and $10 \mathrm{~mL}$ of acetonitrile were added. The suspension was shaken vigorously for $3 \mathrm{~min}$. After addition of $1 \mathrm{~g}$ $\mathrm{NaCl}$ and $4 \mathrm{~g} \mathrm{MgSO}_{4}$, the sample was shaken again, and it was centrifuged (5 min, $5000 \mathrm{rpm}$ ) in order to separate aqueous and organic phases. A $0.5 \mathrm{~mL}$ aliquot of upper organic phase was diluted with deionized water in 1:1 (v/v) ratio, and it was passed through the $0.2 \mu \mathrm{m}$ nylon filter.

The fifth method of sample preparation (Siegel et al, 2010) was performed as follows: In each case approx. $1 \mathrm{~g}$ (exact weights known) of homogenized samples were mixed with $7 \mathrm{~mL}$ water. Subsequently, $2 \mathrm{~mL}$ of $2 \mathrm{M}$ aq. $\mathrm{HCl}$ and $5 \mathrm{~mL}$ EtOAc were added. The resulting ternary phase systems were shaken for $45 \mathrm{~min}$, ultrasonicated for $10 \mathrm{~min}$ (ATM40-3LCD, Madrid, Spain) and shaken again for 45 min. Then, the extracts were transferred into glass cuvettes and centrifuged at $5000 \mathrm{rpm}$ for $15 \mathrm{~min}$ to achieve complete phase separation. Subsequently, $2 \mathrm{~mL}$ of the upper EtOAc layers were transferred into another glass cuvette, and evaporated under a stream of $\mathrm{N}_{2}$ (Reacti-Therm I \#18821, Thermo Scientific, USA). The dry residue was dissolved in $1 \mathrm{~mL}$ of LC/MC grade $\mathrm{MeOH}$, and transferred to an HPLC vial through the Econofilter PTFE $(13 \mathrm{~mm}$, $0.2 \mu \mathrm{m}$ ) syringe filter (Agilent Technologies, China) and stored at $-20^{\circ} \mathrm{C}$.

\section{LC-MS/MS analysis}

The Agilent 1200 series liquid chromatograph, consisting of vacuum degasser, binary pump, autosampler and thermostated column compartment was used for separation of analytes, whose detection was carried out by means of Agilent series $6410 \mathrm{~A}$ triple-quad mass spectrometer with 
electrospray ionization (ESI). MassHunter ver. B.03.01. software (Agilent Technologies) was used for instruments control and data analysis. The injection volume for all samples was $15 \mu \mathrm{L}$. The separation was achieved using a Zorbax Eclipce XDB-C18 column $50 \mathrm{~mm} \times 4.6 \mathrm{~mm}$ i.d., $1.8 \mu \mathrm{m}$ (Agilent Technologies) with a column compartment temperature of $50{ }^{\circ} \mathrm{C}$. The binary mobile phase consisted of $0.05 \%$ aqueous formic acid (A) and methanol (B) and was delivered at a flow rate of $1 \mathrm{~mL} / \mathrm{min}$. Components were eluted in gradient mode, starting with $30 \% \mathrm{~B}$, followed by a linear gradient reaching $70 \% \mathrm{~B}$ in $6 \mathrm{~min}$, then by a linear gradient reaching $100 \% \mathrm{~B}$ in $9 \mathrm{~min}$ and holding for $3.0 \mathrm{~min}$, with post-time of $3 \mathrm{~min}$, and the entire effluent was transferred to mass spectrometer, without flow splitting. ESI parameters were as follows: drying gas $\left(\mathrm{N}_{2}\right)$ temperature $350{ }^{\circ} \mathrm{C}$, flow $9 \mathrm{~L} / \mathrm{min}$, nebulizer gas pressure $45 \mathrm{psi}$, capillary voltage $4 \mathrm{kV}$. Compounds were quantified in negative ionization dynamic selected reactions monitoring mode. Each compound was monitored at determined retention time $\pm 1.5 \mathrm{~min}$.

For the selection of preparation method for the determination of Alternaria toxins from wheat samples by LC-MS/MS in this study, recovery of the extraction step $(\mathrm{R} \%)$, and possible matrix effects (ME) were determined for each sample preparation method. The selected parameters were evaluated by following the guidelines of Commission Decision 2002/657/EC. To evaluate the $\mathrm{R} \%$ of three Alternaria toxins, blank samples were spiked with analyte standards at one concentration level, prior to extraction, and after extraction for the ME. The spiking level was $20 \mu \mathrm{gg}^{-1}$, and samples were prepared in three replicates for each preparation method. The spiked samples were left at room temperature for half an hour in the dark. Thereafter, the samples were extracted, and stored at -20 ${ }^{\circ} \mathrm{C}$ until the analysis by LC-MS/MS. Fivepoint calibration curves for all mycotoxins were plotted at different concentrations. Linear regression was used to plot the peak area ratio $(y)$ of each mycotoxin to its concentration. Each point was repeated in duplicate. The matrix effect (ME) and the recovery of the extraction step $(\mathrm{R} \%)$ were calculated, using a protocol presented by Matuszewski, Constanez, and ChavezEng (2003) with the following formulas:

$\mathrm{ME}(\%)=\mathrm{B} / \mathrm{A} \times 100$

$\mathrm{R}(\%)=\mathrm{C} / \mathrm{B} \times 100$

where $A$ is the average peak area in the standard solution, $B$ is the average peak area in the spike after extraction, and $\mathrm{C}$ is the average peak area in the sample spiked before extraction.

\section{RESULTS AND DISCUSSION}

The aim of this study was to choose the most suitable preparation method for the determination of Alternaria toxins with acceptable level of recovery of the extraction step $(\mathrm{R} \%)$, and minimal matrix effect (ME\%) of target analytes from wheat samples. Also, existing methods were adapted to simultaneously analyse and quantify three Alternaria toxins $(\mathrm{AOH}$, AME and TeA) in wheat samples, by using single clean-up procedure and analytical run.

Modification of the method for preparation of wheat samples by Streit et al. (2013) (first method) involved that the $10 \mathrm{~mL}$ (exact volume known) of filtered crude extracts were transferred into glass cuvette, and evaporated under a stream of $\mathrm{N}_{2}$ in order to concentrate the target analytes and the dry residue was dissolved in $1 \mathrm{~mL}$ of DMF, and transferred to an HPLC vial through the $0.2 \mu \mathrm{m}$ PTFE syringe filter, instead of diluting extract (ratio 1:1) and direct injection into the LC-MS/MS instrument. Mix of $\mathrm{AOH}, \mathrm{AME}$ and TeA standards was also prepared in DMF in concentation range of $5-25 \mu \mathrm{g} \mathrm{mL}{ }^{1}$. The second method of sample preparation was selected because this sample preparation method was used for the simultaneous detection and quantification of a broad spectrum of mycotoxins and other meta-bolites by a QTrap 5500 LC-MS/MS System (Streit et al., 2013). The third method of sample preparation was selected because, in this way prepared, tomatoes samples showed excellent recoveries for five Alternaria toxins (close to $100 \%$ ) (Reinhold and Bartels, 2010). The modified QuEChERS procedure (fourth method) was selected since it is applied in the multi-mycotoxin (Rasmussen et al., 2010). 


\section{Table 1.}

Molecular weight (MW), retention times ( $\mathrm{t}_{\mathrm{r}}$ ), the $\mathrm{m} / \mathrm{z}$ of precursor ion (Q1), $\mathrm{m} / \mathrm{z}$ of monitored product ion (Q3), fragmentor voltage (FV), and collision energy (CE) of Alternaria toxins

\begin{tabular}{cccccccc}
\hline $\begin{array}{c}\text { Alternaria } \\
\text { toxins }\end{array}$ & $\begin{array}{c}\mathrm{MW} \\
\left(\mathrm{g} \mathrm{mol}^{-1}\right)\end{array}$ & $\begin{array}{c}\text { Dwell time } \\
(\mathrm{ms})\end{array}$ & $\begin{array}{c}\mathrm{t}_{\mathrm{r}} \\
(\mathrm{min})\end{array}$ & Q1 & Q3 & FV $(\mathrm{V})$ & $\mathrm{CE}(\mathrm{V})$ \\
\hline $\mathrm{AOH}$ & 258.2 & 0.1 & 4.92 & 257.2 & $215 / 213$ & $180 / 180$ & $25 / 20$ \\
$\mathrm{AME}$ & 272.3 & 0.1 & 6.93 & 271.3 & $256 / 228$ & $130 / 160$ & $20 / 30$ \\
$\mathrm{TeA}$ & 197.2 & 0.1 & 3.99 & 196.2 & $139 / 112$ & $170 / 170$ & $15 / 20$ \\
\hline
\end{tabular}

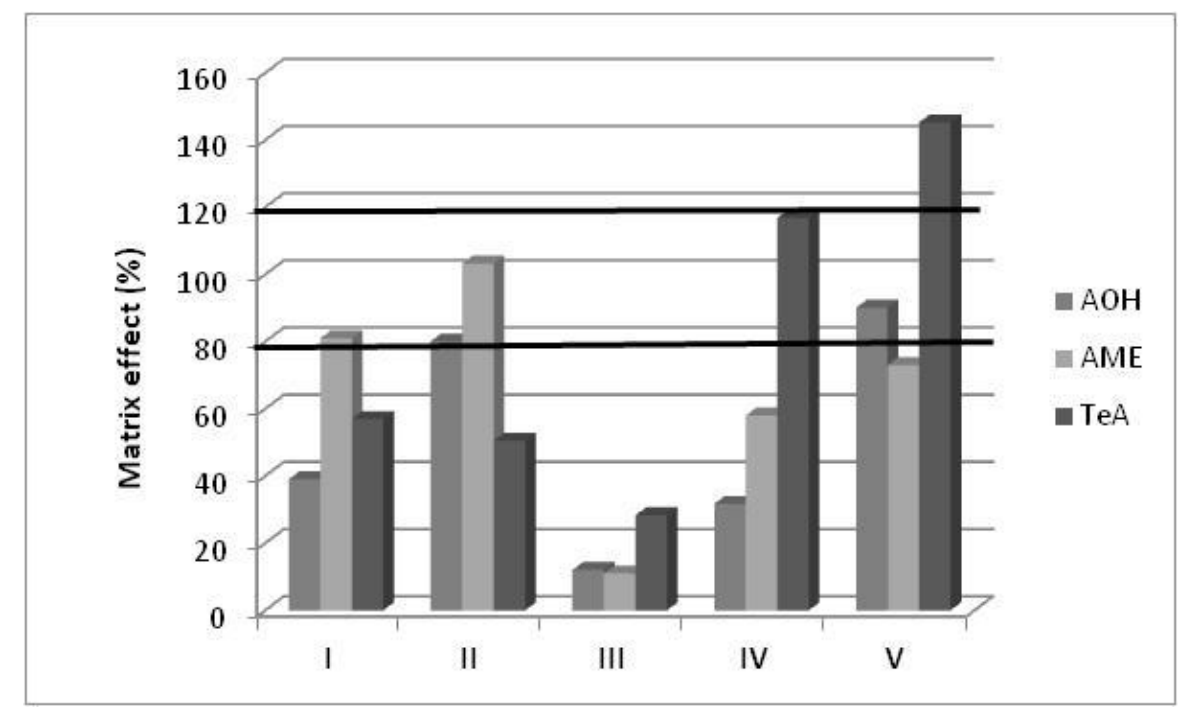

Figure 1. The influence of the sample preparation technique (I - by Streit et al. (2013); II - by Streit et al. (2013); III - by Reinhold and Bartels (2010); IV- by Rasmussen et al. (2010); $\mathrm{V}$ - by Siegel et al. (2010)) on the matrix effects of wheat sample on the response of each mycotoxin at concentration of $20 \mathrm{~g} \mathrm{~kg}^{-1}$. The tolerance level of matrix effect is shown between the two lines

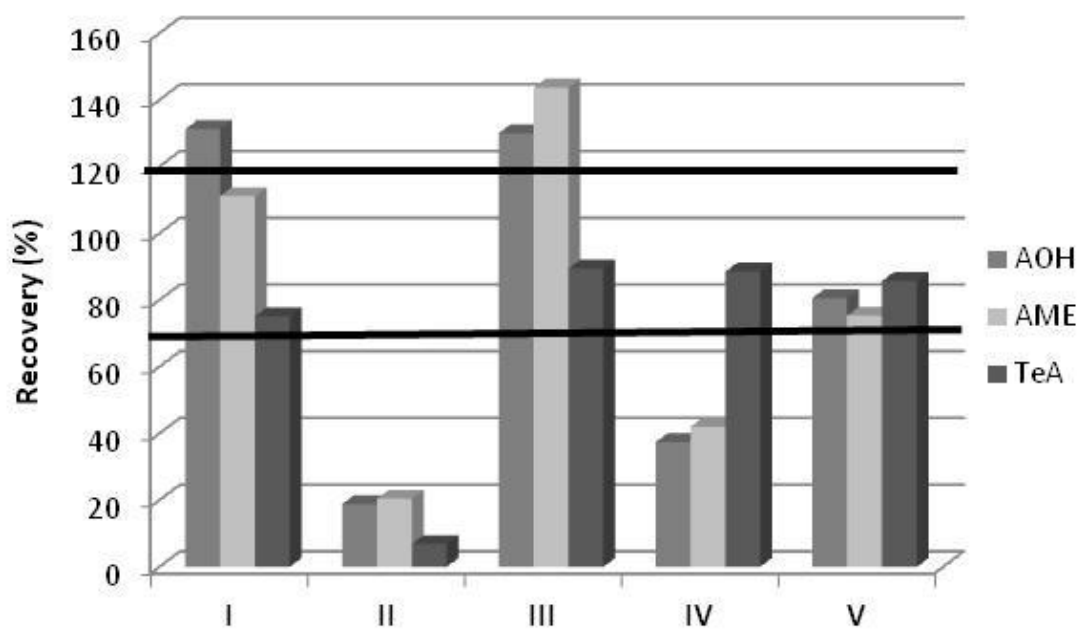

Figure 2. Recoveries of target analytes at $20 \mu \mathrm{g} \mathrm{kg}^{-1}$ level, using different methods of sample preparation (I - by Streit et al. (2013); II - by Streit et al. (2013); III - by Reinhold and Bartels (2010); IV- by Rasmussen et al. (2010); V- by Siegel et al. (2010)). The tolerance level of recovery is shown between the two lines 
Modification of method for wheat sample preparation by Siegel et al., (2010) (fifth method) involved that the $2 \mathrm{~mL}$ of the upper EtOAc layer were transferred into another glass cuvette, and evaporated under a stream of $\mathrm{N}_{2}$ in order to concentrate the target analytes and the dry residue was dissolved in $1 \mathrm{~mL}$ methanol, instead of direct injection into the LCMS/MS instrument. Mix of $\mathrm{AOH}, \mathrm{AME}$ and TeA standards was also prepared in methanol in concentation range of $5-25 \mu \mathrm{g}$ $\mathrm{mL}^{\cdot 1}$.

Ionisation efficiencies were evaluated on Alternaria toxins standard solution at 3000 $\mu \mathrm{g} \mathrm{kg}{ }^{-1}$ and the most intense characteristic MRM transitions were chosen for each analyte. Chromatographic and mass spectrometer data are summarized in Table 1.

Matrix effects are common problem that occurs when using LC-MS or MS/MS, and thus have an adverse effect on the analytical results. The response of the target compound can be enhanced or suppressed due to the interfering matrix components, which is commonly known as signal suppression/enhancement effect (SSE). A value close to $100 \%$ indicates that there is no significant matrix effect, while values $>100 \%$ and $<100 \%$ indicate signal enhancement and signal suppression, respectively. A range between $(-20)$ and $+20 \%$ ME or SSE in between 0.8 and 1.2 was considered as tolerable (Frenich et al., 2011; Yogendrarajah et al., 2013). Values outside this range indicate severe $M E$. The ME of different preparation methods on target analytes is shown in Figure 1.

It can be seen that the signal suppression effect was very prominent almost for all target analytes and almost for all applied methods of sample preparation. It is particularly strongly expressed in the third method of sample preparation (SPE). It is also remarkable that the fifth preparation method leads to a signal enhancement for TeA (ME>120\%). High matrix effect was observed for target analytes in all tested preparation methods, suggesting that it is mandatory to perform matrix-mached calibrations.
Mean recoveries for all the tested preparation methods for the determination of three Alternaria toxins are shown in Figure 2.

It can be seen that the acceptable range of required performance criteria (EC 401/2006) of the mean recoveries for $\mathrm{AOH}, \mathrm{AME}$ and TeA was observed using the fifth preparation method for determination of analytes of interest. Mean recoveries for $\mathrm{AOH}, \mathrm{AME}$ and TeA were 81,75 and $86 \%$, respectively. On the other hand, the second sample preparation method does not provide a satisfactory recovery (extraction efficiency) for target analytes. In the case of the application of the first, third and fourth method of sample preparation, one or two analytes of interest does not meet the established criteria for recoveries (extraction efficiency).

\section{CONCLUSIONS}

Among all tested preparation methods for the determination of the content of three Alternaria toxins in wheat samples, the fifth method of preparation is shown to be satisfactory in terms of acceptable effectiveness of the extraction of the analytes of interest. Since this method shows significant matrix effects on the LC-MS/MS analysis, it is necessary to employ matrixmatched callibration to overcome these problems. Furthermore, complete validation of the method will be done for determination of the content of three Alternaria toxins in wheat samples by LC-MS/MS.

\section{ACKNOWLEDGEMENTS}

This study was supported by the Ministry of Education, Science and Technological Development of the Republic of Serbia, Project No. III 46001.

\section{REFERENCES}

1. An, Y. H., Zhao, T. Z., Miao, J., Liu, G. T., Zheng, Y. Z., Xu, Y. M., et al. (1989). Isolation, identification, and mutagenicity of alternariol monomethyl ether. Journal of Agricultural and Food Chemistry, 37, 1341-1343.

2. Anastassiades, M, Lehotay, S. J., Stajnbaher, D., Schenck, F. J. (2003). Fast and easy multiresidue method employing acetonitrile extraction/partitioning and "dispersive solid-phase extraction" for the determination of pesticide 
residues in produce. Journal of AOAC International, 86, 412-431.

3. Barkai-Golan R., (2008). Alternaria mycotoxins. In: Mycotoxins in fruits and vegetables. Eds Barkai-Golan R and Nachman P. Academic Press, San Diego, CA, USA, 185-203.

4. Berthiller, F., Burdaspal, P., Crews, C., Iha, M. H., Krska, R., Lattanzio, V.M.T., MacDonald, S., Malone, B., Maragos, C., Solfrizzo, M., Stroka, J., Whitaker, T. B. (2014). Developments in mycotoxin analysis: an update for 2012-2013. World Mycotoxin Journal, 7, 3-33.

5. Bottalico, A. and Logrieco, A., (1992). Alternaria plant diseases in Mediterranean countries and associated mycotoxins. In: Alternaria Biology, plant diseases and metabolites. Eds Chełkovski $\mathrm{J}$ and Visconti A. Topics in Secondary Metabolism, 3, 209-232.

6. Brugger, E. M., Wagner, J., Schumacher, D. M., Koch, K., Podlech, J., Metzler, M., et al. (2006). Mutagenicity of the mycotoxin alternariol in cultured mammalian cells. Toxicology Letters, 164, 221-230.

7. Desphande, S.S., (2002). Chapter 11. Fungal Toxins. In: Handbook of food toxicology. Marcel Dekker, Inc., New York, Basel, 387-456.

8. Commission regulation 401/2006, Official Journal of the European Union, L 70/12.

9. EFSA on Contaminants in the Food Chain (CONTAM) (2011). Scientific Opinion on the risks for animal and public health related to the presence of Alternaria toxins in feed and food. EFSA Journal; 9 (10), 2407 Dostupno na: www.efsa.europa.eu/efsajournal.

10. European Commission, Commission Regulation 2002/657/EC of 14 August 2002 implementing council directive 96/23/EC concerning the performance of analytical methods and the interpretation of results. Official Journal of the European Communities, L 221, 8-36.

11. Fernández-Cruz, M. L., Mansilla, M. L., Tadeo, J. L. (2010). Mycotoxins in fruits and their processed products: Analysis, occurrence and health implications. Journal of Advanced Research, 1, 113-122.

12. Frenich, A.G., González, R.R., Gómez-Pérez, M. L., Martínez Vidal, J. L. (2011). Multimycotoxin analysis in eggs using a QuEChERS-based extraction procedure and ultra-high-pressure liquid chromatography coupled to triple quadrupole mass spectrometry. Journal of Chromatography A, 1218, 4349-4356.

13. Köppen, R., Koch, M., Siegel, D., Merkel, S., Maul, R. Nehls, I., (2010). Determination of mycotoxins in foods: current state of analytical methods and limitations. Applied Microbiology and Biotechnology, 86, 1595-1612.

14. Liu, G. T., Qian, Y. Z., Zhang, P., Dong, W. H., Qi, Y. M., \& Guo, H. T. (1992). Etiological role of Alternaria alternata in human esophageal cancer. Chinese Medical Journal, 105, 394400.

15. Matuszewski, B. K., Constanzer, M. L., ChavezEng, C.M. (2003). Strategies for the assessment of matrix effect in quantitativebioana- lytical methods based on HPLC-MS/MS. Analytical Chemistry, 75, 3019-3030.

16. Ostry, V. (2008). Alternaria mycotoxins: an overview of chemical characterization, producers, toxicity, analysis and occurrence in foodstuffs. World Mycotoxin Journal, 1, 175-188.

17. Pero, R. W., Posner, H., Blois, M., Harvan, D., \& Spalding, J. W. (1973). Toxicity of metabolites produced by the Alternaria. Environmental Health Perspectives, 4, 87-94.

18. Rasmussen, R.R., Strom, I.M.L.D., Rasmussen, P. H., Smedsgraard, J., Nielsen, K. F. (2010). Multi-mycotoxin analysis of maize silage by LCMS/MS. Analytical Bioanalytical Chemistry, 397, 765-776.

19. Reinhold, L. and Bartels, I., (2010). LC-MS/MS Determination of Alternaria Toxins in Vegetables and Fruit Beverages. Available on: www.chem.agilent.com/Library/applications/SI01322.pdf

20. Scott, P.M., (2001). Analysis of agricultural commodities and foods for Alternaria mycotoxins. Journal of AOAC International, 84, 18091817.

21. Scott, P.M., Lawrence, G.A., Lau, B.PY. (2006.) Analysis of wines, grape juices and cranberry juices for Alternaria toxins. Mycotoxin Research, 22, 142-147.

22. Scott, P.M. and Kanhere, S.R. (2001). Stability of Alternaria toxins in fruit juices and wine. Mycotoxin Research, 17, 9-14.

23. Scott, P.M., Zhao, W., Feng, S., Lau, B. P.-Y. (2012). Alternaria toxins alternariol and alternariolmonomethyl etherin grain foods in Canada. Mycotoxin Research, 28, 261-266.

24. Shephard, G. S., Berthiller, F., Dorner, J., Krska, R., Lombaert, G. A., Malone, B., Maragos, C., Sabino, M., Solfrizzo, M., Trucksess, M. W., van Egmond, H P., Whitaker, T. B. (2009). Developments in mycotoxin analysis: an update for 2007-2008. World Mycotoxin Journal, 2, 3-21.

25. Shephard, G., S., Berthiller, F., Dorner, J., Krska, R., Lombaert, G. A., Malone, B., Maragos, C., Sabino, M., Solfrizzo, M., Trucksess, M.W., van Egmond, H.P., Whitaker, T.B. (2010). Developments in mycotoxin analysis: an update for 2008-2009. World Mycotoxin Journal, 3, 3-23.

26. Shephard, G., S., Berthiller, F., Burdaspal, P., Crews, C., Jonker, M. A., Krska, R., MacDonald, S., Malone, B., Maragos, C., Sabino, M., Solfrizzo, M., van Egmond, H. P., Whitaker, T. B. (2011). Developments in mycotoxin analysis: an update for 2009-2010. World Mycotoxin Journal, 4, 3-28.

27. Shephard, G., S., Berthiller, F.,Burdaspal, P., Crews, C., Jonker, M.A., Krska, R., MacDonald, S., Malone, B., Maragos, C., Sabino, M., Solfrizzo, M., van Egmond, H. P., Whitaker, T. B. (2012). Developments in mycotoxin analysis: an update for 2010-2011. World Mycotoxin Journal, 5, 3-30.

28. Shephard, G., S., Berthiller, F.,Burdaspal, P., Crews, C., Jonker, M. A., Krska, R., Lattanzio, V.M.T., MacDonald, S., Malone, B., Maragos, C., Sabino, M., Solfrizzo, M., van Egmond, H. 
P., Whitaker, T. B. (2013). Developments in mycotoxin analysis: an update for 2011-2012. World Mycotoxin Journal, 6, 3-30.

29. Siegel, D., Feist, M., Proske, M., Koch, M., Nehls, I. (2010). Degradation of the Alternaria mycotoxins alternariol, alternariol monomethyl ether, and altenuene upon bread baking. Journal of Agricultural and Food Chemistry, 58, 9622-9630.

30. Streit, E., Schwab, Ch.,Suljok, M., Naehrer, K., Krska, R., Schatzmayr, G. (2013). Multi-myco- toxin screening reveals the occurrence of 139 different secondary metabolites in feed and feed ingredients. Toxins, 5, 504-523.

31. Yogendrarajah, P., Van Poucke, CH., De Meulenaer, b., De Saeger, S. (2013). Development and validation of a QuEChERS based liquid chomatography tandem mass spectrometry method for the determination of multiple mycotoxins in spices. Journal of Chromatography $A$, 1297, 1-11.

\title{
ИЗБОР НАЧИНА ПРИПРЕМЕ УЗОРАКА ПШЕНИЦЕ ЗА OДРЕЂИВАЊЕ ALTERNARIA TOКСИНА ПРИМЕНОМ LC-MS/MS
}

\author{
Елизабет П. Јанић Хајнал ${ }^{*}$, Дејан 3. Орчић ${ }^{2}$, Јасна С. Мастиловић ${ }^{1}$, Иван Љ. Миловановић ${ }^{1}$, \\ Јована Ј. Кос ${ }^{1}$
'Универзитет у Новом Саду, Научни институт за прехрамбене технологије у Новом Саду, 21000 Нови Сад, Булевар цара Лазара бр. 1, Србија
2 Универзитет у Новом Саду, Природно математички факултет, \\ 21000 Нови Сад, Трг Доситеја Обрадовића 3, Србија
}

Сажетак: Жита представљају примарни извор људске исхране, при чему у светској производњи пшеница заузима треће место по произведеној количини, а у Србији заузима друго место, одмах иза кукуруза. Као последица климатских промена и глобалног загревања, интензивна појава микобиота на стрмим житима може произвести негативан утицај на безбедност прехрамбених производа, али и на њихов квалитет, што нужно доводи и до великих економских губитака. Иако Fusarium spp. и даље представља главни извор контаминације пшенице микотоксинима, у последљих неколико година због евидентних климатских промена које утичу на пољопривредну производњу дошло је и до појаве других токсигених гљива које су постале важни контаминенти пшенице. Међу њима истичу се гљиве из рода Alternaria, посебно A. alternata која под повољним условима продукује токсичне метаболите као што су алтернариол, алтернариол монометил етар, тенуазонична киселина и друге Alternaria токсине. Имајући у виду токсичност метаболита које продукују поједине врсте гљива рода Alternaria у систему од њиве до трпезе, за спровођење систематске контроле појаве Alternaria токсина неопходе су специфичне и осетљиве аналитичке методе. Течна хроматографија у спрези са масеним детектором (LC-MS/MS) постала је преовлађујућа техника за детекцију и квантификацију Alternaria токсина у храни и храни за животиње. Ограничавајући фрактори су између осталог и понекад лоша ефикасност пречишћавања узорака и недостатак референтних материјала. Циљ овог рада био је да се изабере адекватан начин припреме узорака пшенице за одређивање садржаја Alternaria токсина применом LC-MS/MS технике на основу публикованих начина припреме узорака који се користе у аналитици микотоксина уз евентуалну модификацију истих. Од примењених начина припреме узорака пшенице модификована метода екстракције са етил ацетатом је одабрана као прихватљива у погледу ефикасности екстракције аналита од интереса.

Кључне речи: Alternaria токсини, припрема узорака, пшеница, LC-MS/MS

Received: 1 August 2014. 